\title{
EDITORIAL
}

\section{TRAUMA CARE: HIGHLY DEMANDING, TREMENDOUS BENEFITS}

\section{Professor Mircea Beuran, MD, PhD}

From its beginning, mankind suffered injuries through falling, fire, drowning and human aggression [1]. Although the frequency and the kinetics modifiy over millennia, trauma continues to represent an important cause of morbidity and mortality even in the modern society [1]. Significant progresses in the trauma surgery were due to military conflicts, which next to social sufferance came with important steps in injuries' management, further applied in civilian hospitals. The foundation of modern trauma systems was started by Dominique Jean Larrey (1766-1842) during the Napoleonic Rin military campaign from 1792. The wounded who remained on the battlefield till the end of the battle to receive medical care, usually more than 24 hours, from that moment were transported during the conflict with flying ambulances to mobile hospitals. Starting with the First World War, through the usage of antiseptics, blood transfusions, and fracture management, the mortality decreased from $39 \%$ in the Crimean War (1853-1856) to 10\%. One of the most preeminent figures of the Second World War was Michael DeBakey, who created the Mobile Army Surgical Hospitals (MASH), concept very similar to the Larrey's unit. In 1941, in England, Birmingham Accident Hospital was opened, specially designed for injured people, this being the first trauma center worldwide. During the Golf War (1990-1991) the MASH were used for the last time, being replaced by Forward Surgical Teams, very mobile units satisfying the necessities of the nowadays infantry [1].

Nowadays, trauma meets the pandemic criteria, everyday 16,000 people worldwide are dying, injuries representing one of the first five causes of mortality for all the age groups below 60 [2]. A recent 12-month analysis of trauma pattern in the Emergency Hospital of Bucharest revealed 141 patients, $72.3 \%$ males, with a mean age of $43.52 \pm 19$ years, and a mean New Injury Severity Score (NISS) of $27.58 \pm 11.32$ [3]. The etiology was traffic related in $101(71.6 \%)$, falls in $28(19.9 \%)$ and crushing in $7(5 \%)$ cases. The overall mortality was as high as $30 \%$, for patients with a mean NISS of 37.63 [3].

At the scene, early recognition of severe injuries and a high index of suspicion according to trauma kinetics may allow a correct triage of patients [4]. A functional trauma system should continuously evaluate the rate of over- and under-triage [5]. The over-triage represents the transfer to a very severe patient to a center without necessary resources, while under-triage means a low injured patient referred to a highly specialized center. If under-triage generates preventable deaths, the over-triage comes with a high financial and personal burden for the already overloaded tertiary centers [5]. To maximize the chance for survival, the major trauma patients should be transported as rapid as possible to a trauma center [6]. The initial resuscitation of trauma patients was divided into two time intervals: ten platinum minutes and golden hour [6]. During the ten platinum minutes the airways should be managed, the exsanguinating bleeding should be stopped, and the critical patients should be transported from the scene. During the golden hour all the life-threatening lesions should be addressed, but unfortunately many patients spend this time in the prehospital setting [6]. These time intervals came from Trunkey's concept of trimodal distribution of mortality secondary to trauma, proposed in 1983 [7]. This trimodal distribution of mortality remains a milestone in the trauma education and research, and is still actual for development but inconsistent for efficient trauma systems [8]. 
The concept of patients' management in the prehospital setting covered a continuous interval, with two extremities: stay and play/treat then transfer or scoop and run/ load and go. Stay and play, usually used in Europe, implies airways securing and endotracheal intubation, pleurostomy tube insertion, and intravenous lines with volemic replacement therapy. During scoop and run, used in the Unites States, the patient is immediately transported to a trauma center, addressing the immediate life-threating injuries during transportation.

In the emergency department of the corresponding trauma center, the resuscitation of the injured patients should be done by a trauma team, after an orchestrated protocol based on Advanced Trauma Life Support (ATLS). The modern trauma teams include five to ten specialists: general surgeons trained in trauma care, emergency medicine physicians, intensive care physicians, orthopedic surgeons, neurosurgeons, radiologists, interventional radiologists, and nurses. In the specially designed trauma centers, the leader of the trauma team should be the general surgeon, while in the lower level centers this role may be taken over by the emergency physicians.

The implementation of a trauma system is a very difficult task, and should be tailored to the needs of the local population. For example, in Europe the majority of injuries are by blunt trauma, while in the United States or South Africa they are secondary to penetrating injuries. In an effort to analyse at a national level the performance of trauma care, we have proposed a national registry of major trauma patients [9]. For this registry we have defined major trauma as a New Injury Severity Score higher than 15. The maintenance of such registry requires significant human and financial resources, while only a permanent audit may decrease the rate of preventable deaths in the Romanian trauma care (Figure 1) [10].

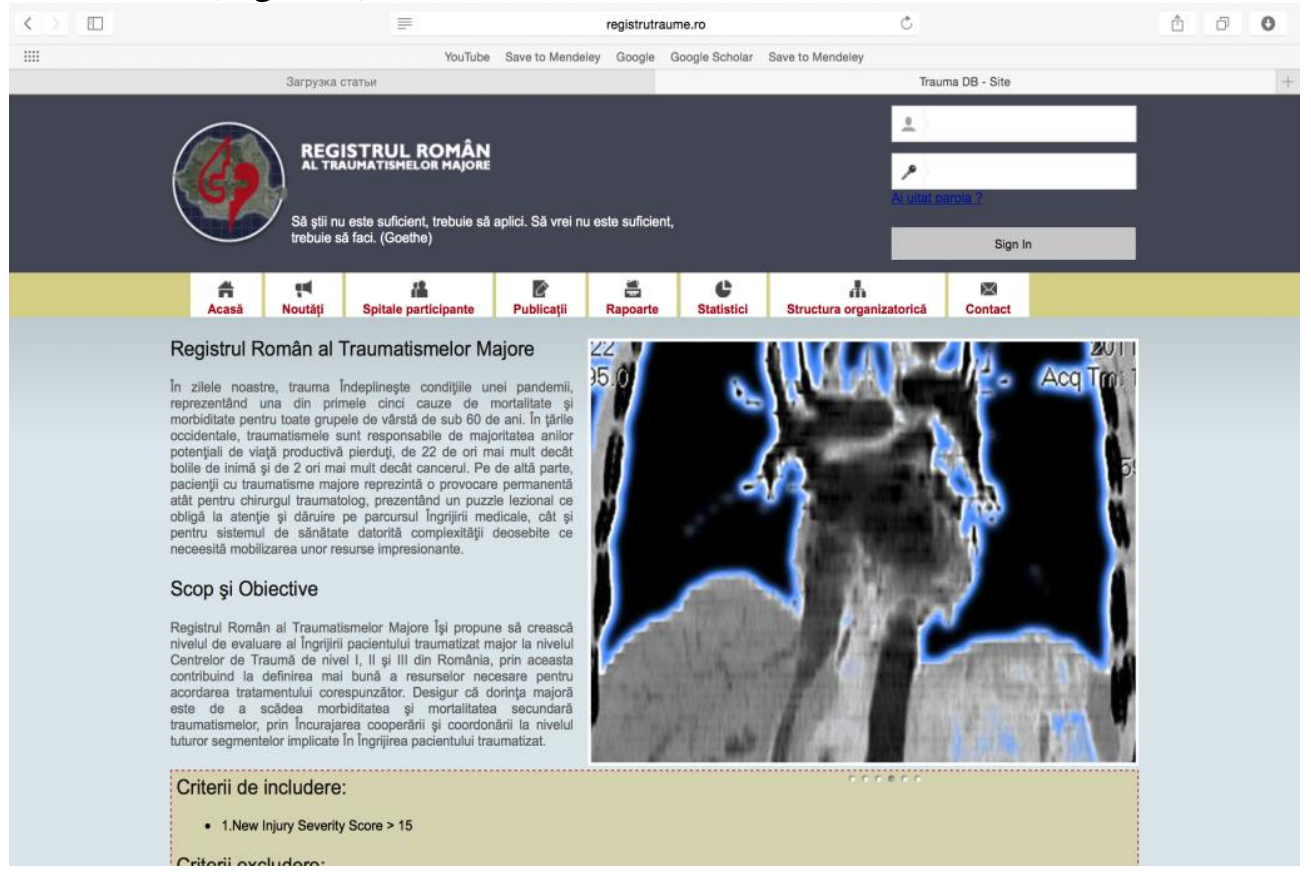

Figure 1 - The website of Romanian Major Trauma Registry (http://www.registrutraume.ro).

USA - In the United States of America there are 203 level I centers, 265 level II centers, 205 level III or II centers and only 32 level I or II pediatric centers, according to the 2014 report of National Trauma Databank [11]. USA were the first which recognized trauma as a public health problem, and proceeded to a national strategy for injury prevention, emergency medical care and trauma research. In 1966, the US National Academy of Sciences and the National Research Council noted that "public apathy to the mounting toll from accidents must be transformed into an action program under strong leadership" [12]. Considerable national efforts were made in 1970s, when standards of trauma care were released and in 1990s when "The model trauma care system plan' [13] was generated. The American College of Surgeons introduced the concept of a national trauma registry in 1989. The National Trauma Databank became functional seven years later, in 2006 being registered over 1 million patients from 600 trauma centers [14]. 
Mortality from unintentional injury in the United States decreased from 55 to 37.7 per 100,000 population, in 1965 and 2004, respectively [15]. Due to this national efforts, $84.1 \%$ of all Americans have access within one hour from injury to a dedicated trauma care [16].

Canada - A survey from 2010 revealed that 32 trauma centers across Canada, 16 Level I and 16 Level II, provide definitive trauma care [18]. All these centers have provincial designation, and funding to serve as definitive or referral hospital. Only $18(56 \%)$ centers were accredited by an external agency, such as the Trauma Association of Canada. The three busiest centers in Canada had between 798-1103 admissions with an Injury Severity Score over 12 in 2008 [18].

Australia - Australia is an island continent, the fifth largest country in the world, with over 23 million people distributed on this large area, a little less than the United States. With the majority of these citizens concentrated in large urban areas, access to the medical care for the minority of inhabitants distributed through the territory is quite difficult. The widespread citizens cannot be reached by helicopter, restricted to near-urban regions, but with the fixed wing aircraft of the Royal Flying Doctor Service, within two hours [13]. In urban centers, the trauma care is similar to the most developed countries, while for people sparse on large territories the trauma care is far from being managed in the "'golden hour", often extending to the "Golden day", [19].

Germany - One of the most efficient European trauma system is in Germany. Created in 1975 on the basis of the Austrian trauma care, this system allowed an over 50\% decreasing of mortality, despite the increased number of injuries. According to the 2014 annual report of the Trauma Register of German Trauma Society (DGU), there are 614 hospitals submitting data, with 34.878 patients registered in 2013 [20]. The total number of cases documented in the Trauma Register DGU is now 159.449, of which $93 \%$ were collected since 2002. In the 2014 report, from 26.444 patients with a mean age of $49.5 \%$ and a mean ISS of 16.9, the observed mortality was 10\% [20].

The United Kingdom - In 1988, a report of the Royal College of Surgeons of England, analyzing major injuries concluded that one third of deaths were preventable [21]. In 2000, a joint report from the Royal College of Surgeons of England and of the British Orthopedic Association was very suggestive entitled "Better Care for the Severely Injured" [22]. Nowadays the Trauma Audit Research network (TARN) is an independent monitor of trauma care in England and Wales [23]. TARN collects data from hospitals for all major trauma patients, defined as those with a hospital stay longer than 72 hours, those who require intensive care, or in-hospital death. A recent analysis of TARN data, looking at the cost of major trauma patients revealed that the total cost of initial hospital inpatient care was $£ 19.770$ per patient, of which $62 \%$ was attributable to ventilation, intensive care and wards stays, $16 \%$ to surgery, and $12 \%$ to blood transfusions [24].

\begin{tabular}{|c|c|c|c|}
\hline $\begin{array}{l}\text { Global } \\
\text { health care } \\
\text { models }\end{array}$ & $\begin{array}{l}\text { Countries } \\
\text { where is } \\
\text { applied }\end{array}$ & Functioning concept & $\begin{array}{l}\text { Total healthcare } \\
\text { costs from GDP }\end{array}$ \\
\hline $\begin{array}{l}\text { Bismarck } \\
\text { model }\end{array}$ & Germany & $\begin{array}{l}\text { Privatized insurance companies (approx. } 180 \\
\text { nonprofit sickness funds). Half of the national } \\
\text { trauma beds are publicly funded trauma centers; } \\
\text { the remaining are non-profit and for-profit private } \\
\text { centers. }\end{array}$ & $11.1 \%$ \\
\hline $\begin{array}{l}\text { Beveridge } \\
\text { model }\end{array}$ & $\begin{array}{l}\text { United } \\
\text { Kingdom }\end{array}$ & $\begin{array}{l}\text { Insurance companies are non-existent. All } \\
\text { hospitals are nationalized. }\end{array}$ & $9.3 \%$ \\
\hline $\begin{array}{l}\text { National } \\
\text { health } \\
\text { insurance }\end{array}$ & $\begin{array}{l}\text { Canada, } \\
\text { Australia, } \\
\text { Taiwan }\end{array}$ & $\begin{array}{l}\text { Fusion of Bismarck and Beveridge models. } \\
\text { Hospitals are privatized, but the insurance } \\
\text { program is single and government-run. }\end{array}$ & $\begin{array}{l}11.2 \% \text { for } \\
\text { Canada }\end{array}$ \\
\hline $\begin{array}{l}\text { The out-of- } \\
\text { pocket } \\
\text { model }\end{array}$ & $\begin{array}{l}\text { India, } \\
\text { Pakistan, } \\
\text { Cambodia }\end{array}$ & $\begin{array}{l}\text { The poorest countries, with undeveloped health } \\
\text { care payment systems. Patients are paying for } \\
\text { more than } 75 \% \text { of medical costs. }\end{array}$ & $3.9 \%$ for India \\
\hline
\end{tabular}

Table 1 - Global health care models with major consequences on trauma care [17]. 
Traumas continue to be a major healthcare problem, and no less important than cancer and cardiovascular diseases, and access to dedicated and timely intervention maximizes the patients' chance for survival and minimizes the long-term morbidities. We should remember that one size does not fit in all trauma care. The Romanian National Trauma Program should tailor its resources to the matched demands of the specific Romanian urban and rural areas.

\section{References}

[1]Beuran M., Negoi I., Paun S. et al. "History of trauma care". Chirurgia (Bucur) 2011; 106: 573-580.

[2]Paun S., Beuran M., Negoi I. et al. "Trauma--epidemiology: where are we today?". Chirurgia (Bucur) 2011; 106: 439-443.

[3]Stoica B, Paun S, Tanase I et al. "Trauma pattern in a level I east-European trauma center". Journal of Acute Disease.

[4]Beuran M, Negoi I, Paun S et al. "Mechanism of injury--trauma kinetics. What happend? How?". Chirurgia (Bucur) 2012; 107: 7-14.

[5]Beuran M., Negoi I., Paun S. et al. "Trauma scores: a review of the literature”. Chirurgia (Bucur) 2012; 107: 291-297.

[6]Beuran M., Paun S., Gaspar B. et al. "Prehospital trauma care: a clinical review". Chirurgia (Bucur) 2012; 107: 564-570.

[7]Demetriades D., Kimbrell B., Salim A. et al. "Trauma Deaths in a Mature Urban Trauma System: Is "Trimodal" Distribution a Valid Concept?" Journal of the American College of Surgeons 2005; 201: 343348.

[8]Negoi I., Paun S., Hostiuc S. et al. "Mortality after acute trauma: Progressive decreasing rather than a trimodal distribution". Journal of Acute Disease.

[9]Beuran M., Stoica B., Negoi I. et al. "Trauma registry -- a necessity of modern clinical practice". Chirurgia (Bucur) 2014; 109: 157-160.

[10]Beuran M., Negoi I., Paun S. et al. "Quality management in general surgery: a review of the literature". Journal of Acute Disease 2014; 3: 253-257.

[11]NTDB. Annual Report of National Trauma Databank. In. 2014.

[12]Research CoN. Accidental Death and Disability: The Neglected Disease of Modern Society. Washington: National Academy of Sciences 1966.

[13]Hofman M., Pape H. "Trauma Care Systems". In Oestern H, Trentz O, Uraneus S (eds): "General Trauma Care and Related Aspects". Springer 1-19.

[14]Evans DC. "From trauma care to injury control: a people's history of the evolution of trauma systems in Canada". Canadian Journal of Surgery 2007; 50: 364-369.

[15]MMWR. State Specific Unintentional Injury Deaths-United States, 1999-2004. Atlanta: Centre for Disease Control 2007.

[16]Branas C., MacKenzie, EJ., Williams, JC., et al. Access to trauma centers in the United States. JAMA 2005; 293: 2626-2633.

[17]Lee DS, Mir HR. "Global systems of health care and trauma". J Orthop Trauma 2014; 28 Suppl 10: S810.

[18]Hameed S.M., Schuurman N., Razek T. et al. "Access to trauma systems in Canada". J Trauma 2010; 69: 1350-1361; discussion 1361.

[19]Croser JL. "Trauma care systems in Australia". Injury 2003; 34: 649-651.

[20]DGU T. Annual Report 2014. In. 2014.

[21]The management of patients with major injuries. Commission on the provision of surgical services - The Royal College of Surgeons of England. 1988.

[22]Albert J, Phillips H. “Trauma care systems in the United Kingdom”. Injury 2003; 34: 728-734.

[23]Trauma Audit Research network (TARN). Available from: https://http://www.tarn.ac.uk/Home.aspx

[24]Campbell H.E., Stokes E.A., Bargo D.N. et al. "Quantifying the healthcare costs of treating severely bleeding major trauma patients: a national study for England". Crit Care 2015; 19: 276. 